IZA DP No. 8604

Socio-demographic Model of Gender Gap in Expected and Actual Wages in Estonia

Kristjan Vassil

Raul Eamets

Pille Mõtsmees

October 2014 


\title{
Socio-demographic Model of Gender Gap in Expected and Actual Wages in Estonia
}

\author{
Kristjan Vassil \\ University of Tartu \\ Raul Eamets \\ University of Tartu \\ and IZA
}

Pille Mõtsmees

University of Tartu

\section{Discussion Paper No. 8604 \\ October 2014}

\author{
IZA \\ P.O. Box 7240 \\ 53072 Bonn \\ Germany \\ Phone: +49-228-3894-0 \\ Fax: +49-228-3894-180 \\ E-mail: iza@iza.org
}

Any opinions expressed here are those of the author(s) and not those of IZA. Research published in this series may include views on policy, but the institute itself takes no institutional policy positions. The IZA research network is committed to the IZA Guiding Principles of Research Integrity.

The Institute for the Study of Labor (IZA) in Bonn is a local and virtual international research center and a place of communication between science, politics and business. IZA is an independent nonprofit organization supported by Deutsche Post Foundation. The center is associated with the University of Bonn and offers a stimulating research environment through its international network, workshops and conferences, data service, project support, research visits and doctoral program. IZA engages in (i) original and internationally competitive research in all fields of labor economics, (ii) development of policy concepts, and (iii) dissemination of research results and concepts to the interested public.

IZA Discussion Papers often represent preliminary work and are circulated to encourage discussion. Citation of such a paper should account for its provisional character. A revised version may be available directly from the author. 
IZA Discussion Paper No. 8604

October 2014

\section{ABSTRACT}

\section{Socio-demographic Model of Gender Gap in Expected and Actual Wages in Estonia}

Estonia ranks consistently on top of the list of countries with the largest gender pay gap. However, irrespective of abundant aggregate level evidence, little is known what motivates the gap at the individual level. In this paper we precisely address the issue of gender pay gap at the individual level. We examine how large is the gender pay gap in actual and expected wages and how it can be explained. We use a rich dataset from Estonian Labour Force Survey on actual wages, and the data from CV Keskus on people's wage expectations. Findings show that education and ethnicity are primary sources for gender based wage discrimination hinting at structural cleavages in Estonian society. Results have major policy implications for other multi-lingual countries with similar historical background.

JEL Classification: J16, J31

Keywords: $\quad$ gender wage gap, Estonia, expected wage gap, actual wage gap

Corresponding author:

Raul Eamets

University of Tartu

Faculty of Economics and Business Administration

Narva mnt. 4

Tartu, 51009

Estonia

E-mail: raul.eamets@ut.ee 


\section{Introduction}

The main interest of this paper is to explain and contrast the gender gap in actual and expected wages, and see whether the differences are at the same level. Moreover, we investigate whether the selected variables explain the gender gap in real as well as in desired wages. We draw on the case of Estonia, a country that has the largest unconditional gender gap in Europe (Eurostat, 2014). We analyse differences in men's and women's wages using Estonian Labour Force Survey data and the 2009 data from CV Keskus.

The gender gap in wages exists despite recent increases in women's capital acquisition and labour force participation, as well as the implementation of antidiscrimination policies (Nyhus and Pons, 2012). The average gender pay gap in the European Union in 2011 was 16\% (Eurostat, 2014) and in OECD countries women earned between 10 to 25 percent less than men (Böheim et al., 2013). Although the gap is getting smaller and a large part of it is due to differences in observed characteristics (Weichselbaumer and Winter-Ebmer, 2005; Stanley and Jarrell, 1998), the unexplained part still provokes researchers' attention - particularly because it greatly varies at the country level.

Estonia, together with other Baltic countries, has inherited high female employment rates already from the communist times. During the Soviet regime the official ideology attempted to eliminate any kind of gender discrimination and both sexes were equally treated, at least in the official discourse. Therefore, Semykina and Linz (2010) conclude the previous authors' work about transition and argue that gender differences in educational qualifications and experience cannot be employed as useful predictors of gender pay disparity in transition economies as the problem arises from the high education levels and the high labour force participation rates during the Soviet period. Consequently, observed gender differences in human capital characteristics appear to be too small and often in favour of women. However, in reality occupational and sectoral segregation was wide and common. According to Rõõm and Kallaste (2004) women dominated in some occupations and vice versa. Females were traditionally engaged in the service sector (education, trade, etc.), whereas heavy 
industry, transport sector, and agriculture predominantly represented the so-called male occupations that were better paid in comparison with the service sector. Primarily as a result of segregation, but also due to the reason that men were more likely to be promoted than women irrespective of their occupations, wage gaps were wider in Central and Eastern European countries than in Western Europe during the last decade of the socialist era (Newell and Reilly, 2001).

Estonia provides an interesting case for research on gender wage gap for several reasons. The unconditional gender wage gap is 30\%, being the largest in Europe (Eurostat, 2014). Estonia is known for its very high economic freedom (see the index of economic freedom by the Heritage Foundation), and also for its flexible labour market, low union power, and low enforcement of employment protection legislation (Eamets and Masso, 2005). As a result, the wage distribution is wide and the unexplained wage gap by gender (Anspal et al., 2010; Mõtsmees and Meriküll, 2012) and ethnicity (Leping and Toomet, 2008) is large. If we look at the dynamics of wage gap we can see that it has been persistently high throughout the independence (from the beginning of the 1990s). Philips (2001), using the retrospective data of the Estonian Labour Force Survey 1995, concluded that in 1989 men earned on average $30 \%$ more than women, while other socio-demographic and occupational characteristics were similar. Vöörmann (2000), who studied data from the midnineties, points out that women in Estonia were paid less than men in all occupations and that the wages paid to women fell short of the earnings of men by approximately a quarter. The same was found for the period of 1998-2000 (Rõõm and Kallaste, 2004). In addition, the female participation rate is high at $63 \%$, with $71 \%$ for males (see Statistics Estonia general data of labour market). The high participation rate for women might be due to too high reservation wages.

However, irrespective of abundant aggregate level evidence of the large gender pay gap, little is known what motivates the gap at the individual level, and whether it is conditional on other factors. In this paper we precisely address the gender pay gap at the individual level by examining how large the gender pay gap is in actual and expected wages. Moreover, we seek to explain wage differences using a rich dataset from Estonian Labour Force Survey for actual wages and the data from CV Keskus 
for people's wage expectations. Our models use the socio-demographic predictors at the individual level as well as at the job level, and industry specific information to estimate a robust relationship between gender-induced wage differences.

The paper is organised as follows: a brief overview of related literature and previous research is given in the next section. Section 3 presents the data and variables, section 4 provides the model specification, sections 5 and 6 present results of the econometric analyses, and the last section summarises the findings.

\section{Related literature}

Several approaches and factors are offered to explain the gender differences in wages. According to the human capital approach, first proposed by Becker (1957), the differences in earnings could derive from the differences in labour productivity between men and women, or from the discrimination against women by the market (employer, employee, or customer). Mincer (1958) provided the effect of labour market experience or on-the-job training for the determination and distribution of earnings. According to this approach the differences in wages could be explained by individual characteristics related to productivity, such as schooling (Mincer, 1974; Mincer and Polachek, 1974), and the coefficients are then interpreted as the returns to investment or loss from disinvestment in human capital (Becker, 1964). The human capital theory later also explained the ethnic differences in earning and other labour market issues (Polachek, 2003).

Given the traditional division of labour by gender in the family, women tend to accumulate less labour market experience than men. Furthermore, as women anticipate shorter and more discontinuous work lives, they have lower incentives to invest in market-oriented formal education and to on-the-job training. As a result they invest less to human capital than men do. Less human capital also means earning less. The longer hours women spend on housework may also decrease the effort they put into their market jobs compared to men; their control over the worked hours hence also reduce their productivity and wages (Becker, 1985). On the other hand, England and Browne (1992) argued in their comprehensive literature overview that there is no 
evidence that gender differences in effort explain any of the gender gaps in pay. According to their views, segregation is perpetuated by a combination of discrimination by employers, gendered socialisation affecting job choices, and institutional inertia. In one of her earlier studies, England (1982) concluded that human capital theory has not generated an explanation for occupational sex segregation, which is considered as one of the major sources for the wage gap.

Hellerstein and Neumark (1999) and Hellerstein, Neumark, and Troske (1999) exploited matched employer-employee data to calculate an indicator for wage discrimination. They estimated the relative marginal products of various worker types, which were then compared with their relative wages. They found that women's marginal product is somewhat below that of men's. Additionally, they found that women are paid significantly less than men, with the wage differential between men and women being generally much larger than the productivity differential. Those wage differentials could also be related to the so-called 'glass ceiling' effect. If we look at studies about some Scandinavian (Datta Gupta et al., 2006 or Albrecht et al., 2003) or EU countries in particular (Arulampalam et al., 2007), we can see that the wage gap of high-skilled women has increased.

Bartolucci (2013) estimated an equilibrium search model to study the extent to which wage differentials between men and women can be explained by differences in productivity, disparities in friction patterns, segregation, and direct wage discrimination. The model features the following aspects: on-the-job search, rentsplitting, and productivity of the heterogeneity in companies and among workers. In terms of wages, he found that the unconditional gender wage gap is 42 percent and it appeared that 65 percent of the gap is accounted for by differences in productivity. According to Hinnosaar and Rõõm (2003) the most commonly mentioned observable differences in the work and human capital of women and men are different working times, horizontal and vertical segregation of the labour market, differences in education, and different lengths of employment.

Labour market discrimination may also affect women's wages and occupations. Discrimination could be described in different ways. In Becker's (1957) model, discrimination is due to the discriminatory tastes of employers, co-workers, or 
customers. Alternatively, in models of 'statistical discrimination', differences in the treatment of men and women arise from average differences between the two groups in the expected value of productivity, which leads to employers discriminating on the basis of that average (Aigner and Cain, 1977). Finally, discriminatory exclusion of women from 'male' jobs can result in an excess supply of labour in 'female' occupations, depressing wages there for otherwise equally productive workers, as in Bergmann's (1974) ‘overcrowding’ model.

Empirically, gender wage discrimination is one of the most widely used theories in the labour economics. Stanley and Jarrell (1998) offer a quantitative assessment of the empirical literature on gender wage discrimination. This meta-regression analysis (MRA) identifies 12 separate factors that are related to the reported gender wage gap, which together explain more than 80 percent of the variation across this research literature. Ever since this meta-analysis was conducted, the number of reported estimates has nearly doubled. It could be then claimed that gender wage discrimination is declining. Almost all studies confirm this (Jarell and Stanley, 2004). In her literature overview, Blau (1998) acknowledges the striking decline in the unexplained gender gap and discusses whether there has been a genuine decline in discrimination or an improvement in women's unmeasured productivity.

These changes are also related to unequal distribution of wage gap between different age cohorts. Blau and Kahn (2000) showed that younger age groups (18-24 and 2534) had considerably smaller wage gaps than individuals in pre-retirement age.

Nyhus and Pons (2012) found that $11.5 \%$ of the observed gender wage gap derives from the differences in the scores of personality traits (mainly in agreeableness and intellect), and that the addition of personality traits to a traditional human capital model reduces the unexplained part of the gender wage gap from $75.2 \%$ to $62.7 \%$. Therefore, these traits represent a valuable addition to the model. Semykina and Lynz (2010) have also pointed out the importance of personality in explaining the pay gap. They found that gender differences in wages are related to differences in the locus of control.

The inference of reservation wages on gender wage gap is of great relevance. The 
observed gender wage gap could be a result of women not participating in the labour market because of their high reservation wages. The reservation wage, the lowest wage for which an individual is willing to work, plays a key role in the theoretical models of job search, labour supply, and labour market participation (see, e.g., Blackaby et al., 2007). There is not a lot of literature about gender reservation wage gap. Baffoe-Bonnie and Ezeala-Harrison (2005) showed that unemployment duration has a significantly different effect on the male and female reservation wages. Brown, Roberts, and Taylor (2011) found that the presence of children, particularly pre-school children, plays an important role in determining the extent of this gap that can be explained by individual characteristics. For individuals without children, the gap essentially cannot be explained, whereas for those with children the explained component is $51 \%$ and for those with pre-school children it is $78 \%$.

Charles (2011) studied the gender wage gap in the maquiladora ${ }^{1}$ industry in Mexico. From the company's perspective, a relatively lower wage for women's work is not discriminatory, given that this lower income entitlement for women is socially accepted. She found that reservation wage changed in the event of economic downturns. Female workers have a lower reservation wage than male workers, and their wages were adjusted downwards according to the economic pressures by the reservation wage of male workers. The alternative for unskilled workers in Mexico is no wage in the unpaid economy or an insecure income from the informal sector.

We also found two earlier studies for Estonian reservation wages. Hinnosaar and Rõõm (2003) found that ceteris paribus, the reservation wage for women was $29 \%$ smaller than that of men. This was supported by a study of Rõõm and Kallaste (2004) who have concluded that women in Estonia settle for lower wages and search for work less actively than men.

Still, there is not much evidence in the literature that confronts reservation wage gap with observed wage gap. However, it is precisely the different patterns explaining reservation wage gap and observed wage gap that help to pin down gender based

\footnotetext{
${ }^{1}$ The maquiladora industry consists of wholly foreign-owned or Mexican-owned subsidiary plants, mainly on the Mexican border, for the assembly, processing, and finishing of duty-free foreign materials and components into products for export essentially towards the USA.
} 
attitudes towards competition and risks that are usually difficult to observe in empirical studies. This is precisely what we aim to achieve in this paper. The following section describes the inferential basis for our study.

\section{Data and variables}

Our inferential basis comprises of two datasets. Firstly, we use the Estonian Labour Force Survey in order to assess the impact of gender on actual earnings. Secondly, we use the data that we extracted from the largest Estonian online job-seeking service, CV Keskus, to assess the impact of gender on expected wages. In the following we will briefly describe both datasets.

Estonian Labour Force Survey (ELFS) is a regular survey carried out by Statistics Estonia in order to monitor employment/unemployment, job conditions, and changes in the labour market (Statistics Estonia, 2014). The survey covers the working-age residents in Estonia between 15 to 74 years of age. It uses a stratified systematic sampling design where strata are defined by the place of residence. In 2009 15,293 interviews were carried out. CATI was the preferred way in which interviews were conducted; however 3.5 percent of all interviews were paper-assisted. Our final sample contains 6,091 individuals because not all respondents disclosed their actual wage. The general survey methodology corresponds to that of the International Labour Organization (ILO).

Data on expected wages is drawn from the major job seeking web service CV Keskus (CV data). ${ }^{2}$ It is the largest online job seeking service in Estonia with offices in the Baltics and Hungary (CV Market) where people upload their CVs in order to find an appropriate job. Among other things, job seekers can also reveal their expected wage. In total in 2009, Estonian database contained more than 200,000 CVs corresponding to about $10-15 \%$ of the total employment in Estonia. We extracted a sample of those individuals who updated their CV between January 2009 and January 2010 (in order to match the period for which we have observed the data on actual wages on ELFS study) and published their wage expectations. Effectively, this yields a sample of

\footnotetext{
2 'CV Keskus available at www.cvkeskus.ee
} 
16,228 individuals actively looking for a (new) job.

\section{Variables}

We use two dependent variables in our subsequent analysis, one measuring actual and another expected wage. Actual wage is measured using ELFS 2009 survey. In its original metric, actual wage varies between 0 and 80,000 $\mathrm{EEK}^{3}$ (mean 8,343 EEK, standard deviation 5,526 EEK). The expected wage is measured using the 2009 data from CV Keskus and it varies between 1,000 to 79,000 EEK (mean 12,311, standard deviation 6,490). Due to the large positive skew, both variables are log-transformed (Figure 1). We also prefer transforming wage variables because it allows us to interpret the effects of explanatory variables as a per cent change on wage induced by a unit change on $X$ instead of a unit change in their absolute values.
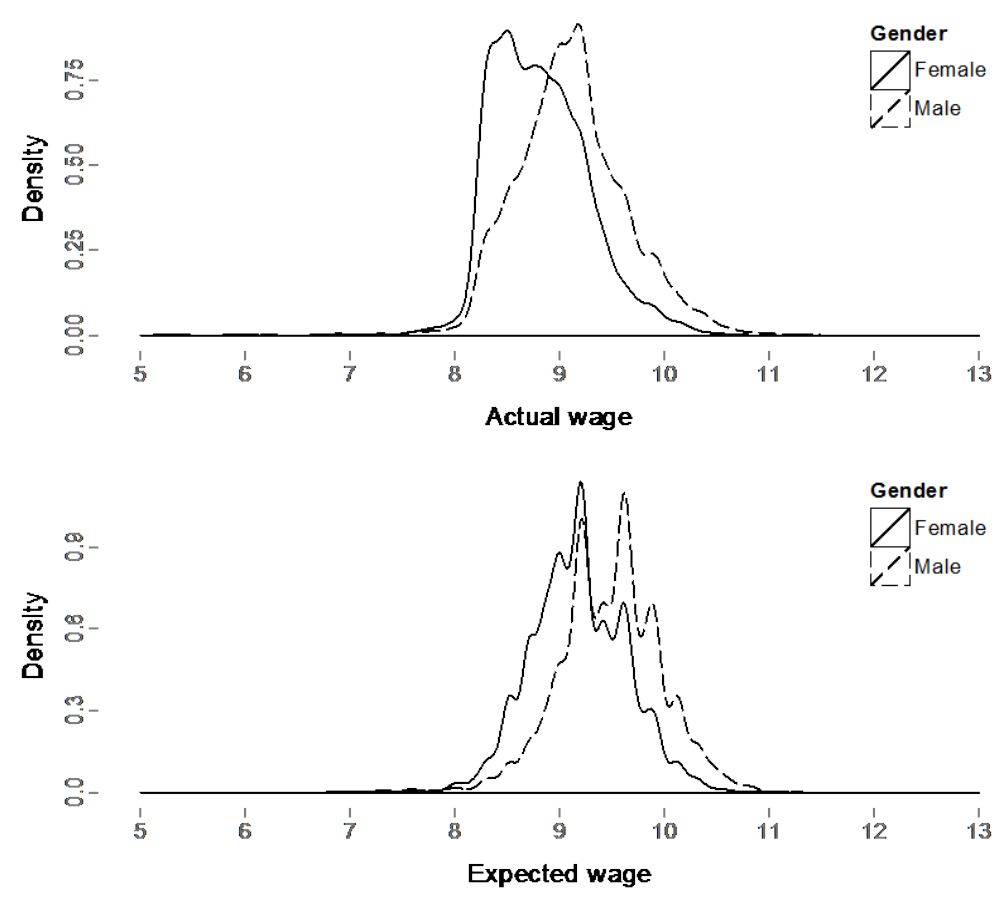

Figure 1 . Kernel density estimates for actual and expected logged wage by gender Source: Labour Force Survey 2009 and CV Keskus 2009, authors' calculations

Our key explanatory variable is gender, coded 1 for males and 0 for females. Based on the relevant literature we also use age (running from 15-77 years of age), number of children (running from 0 to 8), higher education (coded 1 for those with higher

\footnotetext{
${ }^{3}$ Estonia became the member of the Euro-zone in January, 2011. Before that Estonian kroons (EEK) were fixed to the euro with the rate of $1 \mathrm{EUR}=15.6466 \mathrm{EEK}$.
} 
education and 0 otherwise), secondary education (coded 1 for those with secondary education and 0 otherwise), primary education (coded 1 for those with primary education and 0 otherwise), marital status (coded 1 for those who are married or cohabitating and 0 otherwise), white collar worker (based on ISCO job level categories codes from 1 through 4 were coded as 1 indicating white collar workers and codes from 5 through 9 were coded 0 indicating blue collar workers), Estonian ethnicity (coded 1 for ethnic Estonians and 0 otherwise) and industry dummies (coded on the basis of EMTAK ${ }^{4} 2003$ codes yielding dummies for agriculture, manufacturing, construction, commerce, hotels/restaurants/cafeterias, transport, finance, real estate, public administration, and other public services).

\section{Model specification}

In order to estimate the effect of gender on expected and actual wages we specify two ordinary least squared models with the response variables indicating actual and expected wages, respectively. Both outcomes are log-transformed to correct for the large positive skew and heteroscedasticity. ${ }^{5}$

Both models will be fitted in two steps. Firstly, to investigate the uncontrolled impact of gender on wages, we only include gender as a predictor. Secondly, we add education, ethnicity, and age as our primary variables of interest according to our theoretical model. In this stage we also include relevant controls for the number of children, marital status, job type, and industry. Fully specified models take the following form:

$$
\ln \left(\text { wage }_{\text {actual }}\right)=\beta_{0}+\beta_{1} \text { male }+\lambda+\varepsilon
$$

and

\footnotetext{
${ }^{4}$ EMTAK is the local abbreviation of the Estonian Classification of Economic Activities (in Estonian 'Eesti Majanduse Tegevusalade Klassifikaator') based on the international NACE standard.

${ }^{5}$ The latter was obtained by running an OLS-model with dependent variables in their original metric. The Breusch-Pagan test for heteroscedasticy indicated a moderate problem of unequal variance of errors that was effectively corrected with logging the response variables.
} 


$$
\ln \left(\text { wage }_{\text {expected }}\right)=\beta_{0}+\beta_{1} \text { male }+\lambda+\varepsilon
$$

Where the primary parameter of interest is $\beta_{1}$ and vector $\lambda$ includes age, education, ethnicity, and relevant controls (number of children, marital status, job type, and industry).

Finally, because our models use log-transformed dependent variables, we report exponentiated parameters $\exp (\beta)$ that are interpreted as a percent change on wage when independent variable increases by one unit. The explanation of relevant interaction terms are provided with graphical illustrations.

\section{Findings}

We begin by reporting the effect of gender on actual and expected wages. Table 1 displays the outcomes of two models by two dependent variables. ${ }^{6}$ Firstly, we see that in the model excluding all the relevant controls, men's actual wage is 35 percent larger than that of women's. The explained variance is about nine percent, which can be regarded as substantial given that the model is not fully specified. When including primary explanatory variables and controls the pay gap rises by 9 percentage points to 44 percent and the explained variance to 34 percent.

Comparing these findings to gender based differences in expected wages, we first find that in the uncontrolled model the difference between men and women is 34 percent, comparable to that of actual wages. In a fully specified model the difference in expected wages increases to 41 percent.

Taken together we find a sizable pay gap between men and women both for actual and expected wages. Moreover, differences in actual wages (about 44 percent) are comparable to differences in expected wages (about 41 percent), demonstrating that women not only earn less, but they also have lower expectations towards their income. It appears as though women expect a 41 percent lower wage than men and this differences is also actualised in real earnings.

\footnotetext{
${ }^{6}$ Models with all covariate effects reported in Appendix Table A1.
} 
Table 1. The effect of gender on wages

\begin{tabular}{|c|c|c|c|}
\hline & & $\begin{array}{l}\text { ELS data on actual wages } \\
\text { DV: reported actual wage } \\
\text { (logged) }\end{array}$ & $\begin{array}{c}\text { CV data on expected wage } \\
\text { DV: expected wage } \\
\text { (logged) }\end{array}$ \\
\hline \multirow[t]{2}{*}{ Model 1} & $\begin{array}{l}\text { Male } \\
\text { (without controls) }\end{array}$ & $\begin{array}{c}1.35^{* * * *} \\
(0.02)\end{array}$ & $\begin{array}{c}1.34 * * * \\
(0.01)\end{array}$ \\
\hline & $\begin{array}{l}\text { R-squared } \\
\text { Observations }\end{array}$ & $\begin{array}{c}0.09 \\
6,091\end{array}$ & $\begin{array}{c}0.09 \\
16,228\end{array}$ \\
\hline \multirow{2}{*}{ Model 2} & $\begin{array}{l}\text { Male } \\
\text { (all controls) }\end{array}$ & $\begin{array}{c}1.44 * * * \\
(0.02)\end{array}$ & $\begin{array}{c}1.41^{* * *} \\
(0.01)\end{array}$ \\
\hline & $\begin{array}{l}\text { R-squared } \\
\text { Observations }\end{array}$ & $\begin{array}{c}0.34 \\
4,780\end{array}$ & $\begin{array}{c}0.30 \\
7,427\end{array}$ \\
\hline
\end{tabular}

Our next task is to investigate whether the effect of gender on wage is conditional on relevant covariates. We do so by extending our fully specified models for actual expected earnings by combining gender with age, education, and ethnicity. For a better interpretation we extract marginal effects for interaction terms and plot them over the respective values of the independent variable.

We begin by looking at the conditional effect of age. Figure 2 allows us to understand whether the pay gap between men and women has a constant variance over one's age. Notice that Figure 2 is also helpful in assessing the differences in absolute levels of actual and expected wages 

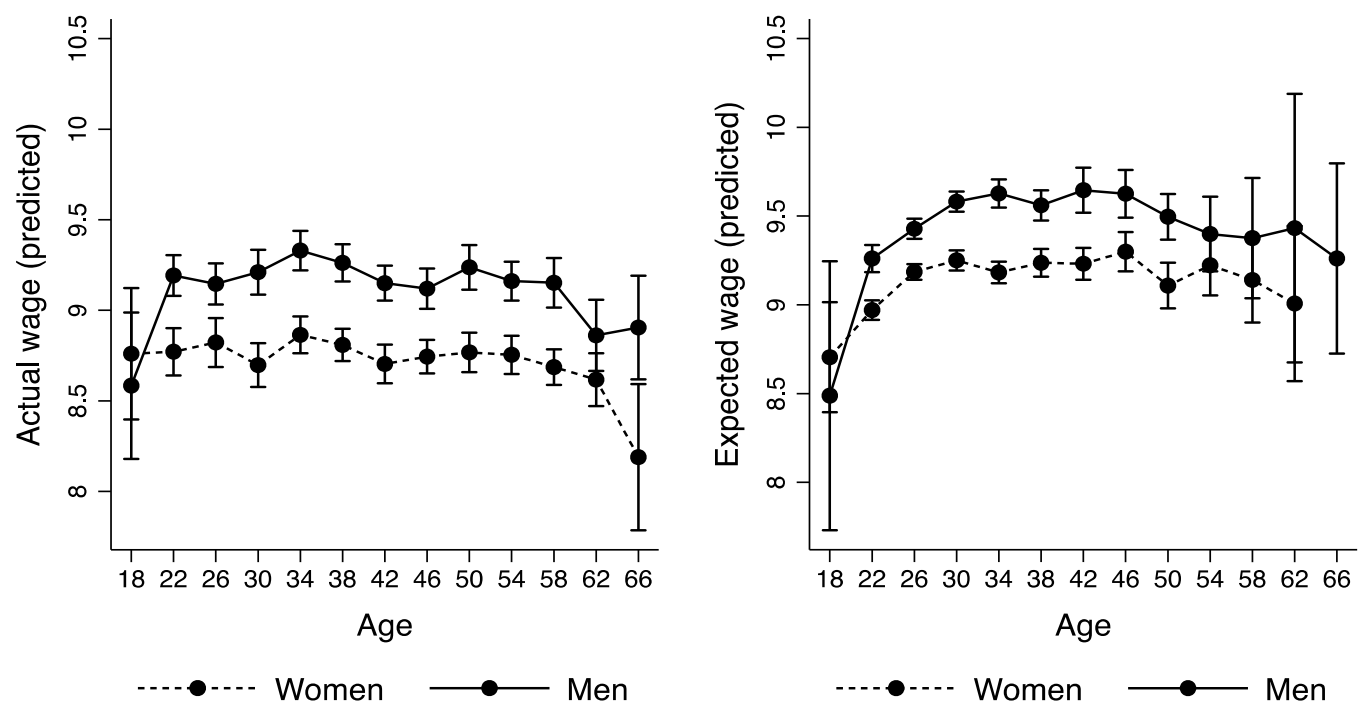

Figure 2. The effect of gender on wages, conditional on age

Source: Labour Force Survey 2009 and CV Keskus 2009, authors’ calculations

First and foremost, we see that the overall level of expected wages is slightly higher than the level of actual earnings for both men and women. Expected wages, unsurprisingly, are larger than actual earnings, most likely containing some room for negotiation. Secondly, we find that in the case of actual wages gender differences are not statistically significant until the age of 22 and from there onwards, the difference remains almost constant until it loses its significance at the age of 62. In other words, the gender gap in actual wages is absent for the young and the old, and is almost equally pronounced for all age categories between 22 and 62. Regarding expected wages we find a similar pattern. Firstly, until the age of 22 no gender differences in expected earnings can be detected, after which the gender gap becomes visible. From the ages of 22 until 54 the gap prevails and appears to be larger towards the age of 34 . The gender gap in expected wages disappears from the age of 54 onwards.

Next, we investigate whether gender gap in wages is conditioned by one's educational attainment and ethnicity. In order to achieve this, we interact gender with education and ethnicity (in our fully-specified model) and plot this three-way interaction on Figure 3. 

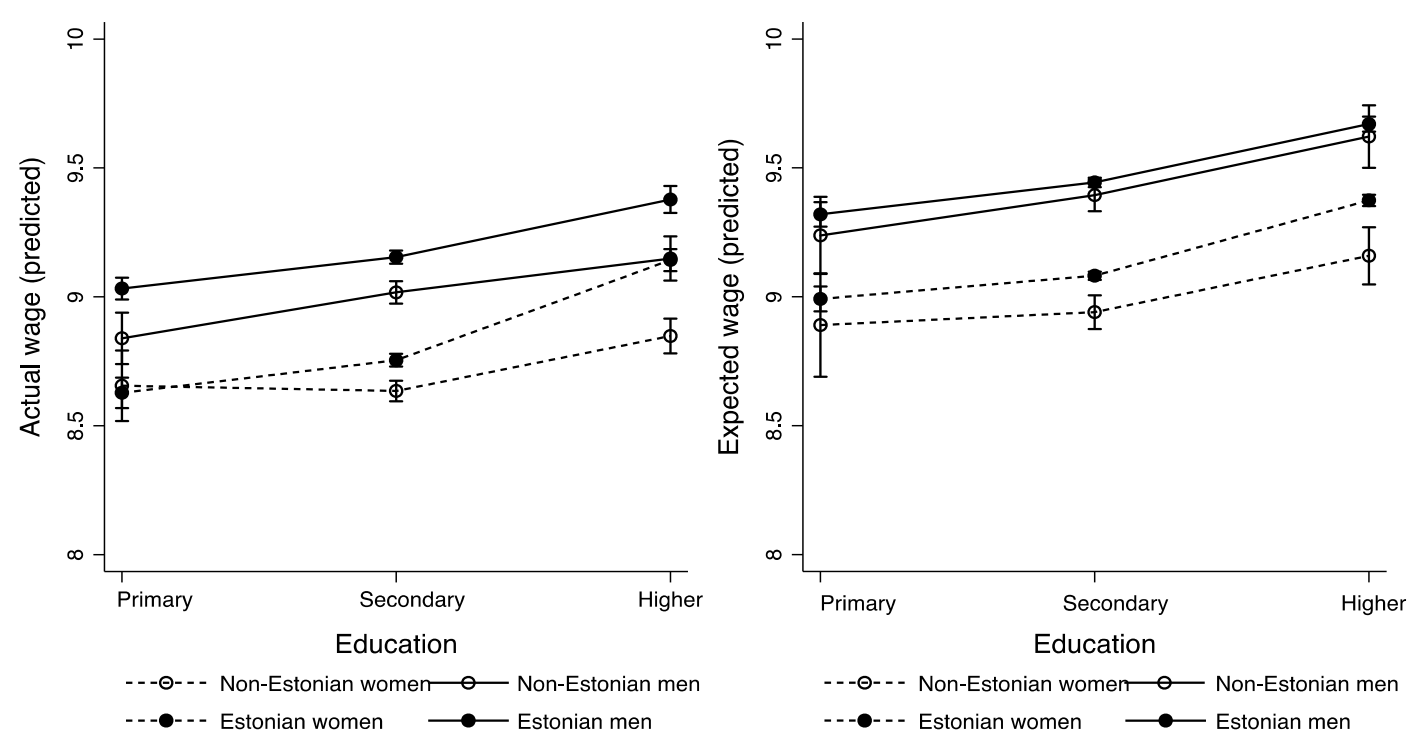

Figure 3. The effect of gender on wages, conditional on ethnicity Source: Labour Force Survey 2009 and CV Keskus 2009, authors' calculations

To start with, we will consider just the effect of education. The most important thing to notice is that men earn considerably more than women of same ethnicity at all levels of education. Secondly, it appeared that Estonian men with secondary education earn roughly the same amount as do Estonian women with higher education. This is particularly alarming since obtaining higher education should have a gender-independent effect on one's earnings: the better qualified, the higher the salary. This is not what we have found. We believe that this is by far the most important finding of our study and has substantial normative implications regarding the gender induced pay gap as well as the policy on gender based income disparities. How can one reconcile the fact that men and women with same educational attainment arrive at different wages and that women with higher education earn about the same as men with secondary education?

It also became apparent that income disparities occur not only between genders but also within genders of different ethnic background. For example, Estonian men earn more than non-Estonian ${ }^{7}$ men at all levels of education. Similarly, Estonian women

\footnotetext{
${ }^{7}$ Non-Estonians are dominantly Russian speakers. According to Census of Population (2011) a largest ethnic group of Russian speakers were ethnic Russians (24,8\%) followed by Ukrainians (1,7\%), Belorussians (less 0,9 \%) etc. There are some industries historically dominated by Russian speakers like railway transport, mining,
} 
earn more than non-Estonian women, except at the level of primary education. We take from this that gender's effect on income difference is to a large degree amplified by one's ethnicity. In other words, ethnicity further discriminates the already existing income disparities induced by gender. We gather from this that only women's expectations towards their wage are affected by ethnicity.

Interestingly, ethnicity plays a much smaller role in expected wages. Estonian men have about the same expectations toward their salary as non-Estonian men. Regarding women, Estonian women expect a slightly higher salary than their non-Estonian counterparts. Thus, ethnicity appears to differentiate expected wages among women, but not among men. However, the dramatic difference of education still prevails also in regard to expected wages. In particular, we find that Estonian women with higher education expect a salary that is comparable to that of Estonian and non-Estonian men with secondary education. Similarly to the actual wages, expectations are considerably lower for Estonian women with higher education as compared to men, and even more so for non-Estonian women.

\section{Robustness}

Regarding the robustness of our findings presented in Table 1 we are primarily concerned with two caveats. Firstly, engagement in the job market is not a random choice neither for men nor women. Moreover, men and women self-select themselves non-randomly into educational levels, job categories, industries, etc., that inevitably yield different wages at the outset. Therefore, comparing men and women in the naive model merits further concern about whether the findings stand a more scrutinised empirical test - one that explicitly accounts for the non-random bias due to the selfselection process. Secondly, depending on the set of control variables, chosen functional form, or different observation subsets (see the interaction terms presented above) our findings may be, at least to some degree, model dependent (cf., Ho et al., 2007). In other words, we are concerned whether seemingly minimal changes in our model specification can lead to substantial changes in findings.

and electricity production. Russian speakers are mostly located in Ida-Virumaa county (close to the Russian border, North West Estonia) and in capital Tallinn. 
In order to account for potential confounding effects of self-selection and model dependence, we check the robustness of our findings by using genetic matching, a form of multivariate propensity score matching (Diamond and Sekhon, 2005). By doing so we seek to balance the sample of men and women in all relevant covariates. Essentially we create a new dataset where the treatment variable (men) will be close to being independent of the background covariates, "which renders any subsequent parametric adjustment either irrelevant or less important” (Ho et al., 2007). We recognise that normally immutable characteristics (such as gender or race) are not used as ideal treatment indicators in matching exercises (cf., Boyd, Epstein, \& Martin, 2010). However, we follow Rubin (2006) and argue that matching is an intuitive strategy when one seeks to achieve balance between two subsamples in order to offer unbiased comparison between men and women with similar backgrounds (age, education, marital status) as well as work characteristics (job level, industry). Furthermore, as we do not interpret the effect of gender on wages causally, matching on immutable characteristic is of lesser concern in this case.

We prefer using matching instead of Heckman's 2-stage selection model (which is commonly used to correct the samples for self-selection biases) because model adjustment techniques are sensitive to small specification adjustments, such as for example the selection of variables comprising exclusion restrictions, and thus may even further increase model dependency.

\section{Matching}

We define the treatment indicator coded 1 for males (treated) and 0 for females (control). We use genetic matching ${ }^{8}$ (Diamond and Sekhon, 2005) and thus make use of two sets of variables, one for exact matching and one for genetic matching - both used simultaneously in one algorithm. For exact matching we use ten dummy variables indicating industries, in which the respondent works; also, marital status, white collar workers, and ethnicity. Genetic matching is achieved by using age, number of children, and education. Table 2 demonstrates the balance before and after matching by those variables for which genetic matching was used.

\footnotetext{
${ }^{8}$ We use MatchIt package version 2.4-21 implemented for R.
} 
Table 2. Balance before and after matching

\begin{tabular}{|c|c|c|c|c|c|c|c|c|}
\hline & \multicolumn{4}{|c|}{ ELFS data } & \multicolumn{4}{|c|}{ CV Keskus data } \\
\hline & \multicolumn{2}{|c|}{ Raw } & \multicolumn{2}{|c|}{ Matched } & \multicolumn{2}{|c|}{ Raw } & \multicolumn{2}{|c|}{ Matched } \\
\hline & Male & Female & Male & Female & Male & Female & Male & Female \\
\hline Age & 41.02 & 42.55 & 41.02 & 41.01 & 32.42 & 31.73 & 32.42 & 32.41 \\
\hline Children & 0.69 & 0.67 & 0.69 & 0.67 & 0.86 & 0.94 & 0.86 & 0.86 \\
\hline Higher e. & 0.15 & 0.25 & 0.15 & 0.15 & 0.26 & 0.32 & 0.26 & 0.26 \\
\hline Secondary e. & 0.65 & 0.66 & 0.65 & 0.65 & 0.65 & 0.61 & 0.65 & 0.65 \\
\hline Primary e. & 0.20 & 0.10 & 0.20 & 0.20 & 0.10 & 0.07 & 0.10 & 0.10 \\
\hline Observations & 2352 & 2428 & 2352 & 2339 & 3120 & 4307 & 3120 & 4216 \\
\hline
\end{tabular}

Note on ELFS data: 2352 males (treated units) matched to 2339 females (control units), 89 females unmatched. Note on CV Keskus data: 3120 males (treated units) matched to 4215 females (control units), 91 females unmatched

Source: Labour Force Survey 2009 and CV Keskus 2009, authors’ calculations

Next, we estimated two identical models using the same model specification displayed in equations 1 and 2. Our goal was to observe whether parameters of interest differ in any substantial fashion from those of the naive model. Comparison is offered in Table $3 .^{9}$

Table 3. The effect of gender on wages

\begin{tabular}{|c|c|c|c|c|c|}
\hline & & \multicolumn{2}{|c|}{$\begin{array}{l}\text { ELS data on actual wages } \\
\text { DV: reported actual wage } \\
\text { (logged) }\end{array}$} & \multicolumn{2}{|c|}{$\begin{array}{l}\text { CV data on expected wage } \\
\text { DV: expected wage } \\
\text { (logged) }\end{array}$} \\
\hline & & Raw & Matched & Raw & Matched \\
\hline \multirow[t]{2}{*}{ Model 1} & $\begin{array}{l}\text { Male } \\
\text { (without controls) }\end{array}$ & $\begin{array}{c}1.35^{* * *} \\
(0.02)\end{array}$ & $\begin{array}{c}1.38^{* * *} \\
(0.02)\end{array}$ & $\begin{array}{c}1.34^{* * *} \\
(0.01)\end{array}$ & $\begin{array}{c}1.37^{* * *} \\
(0.01)\end{array}$ \\
\hline & $\begin{array}{l}\text { R-squared } \\
\text { Observations }\end{array}$ & $\begin{array}{c}0.09 \\
6,091\end{array}$ & $\begin{array}{c}0.10 \\
4,691\end{array}$ & $\begin{array}{c}0.09 \\
16,228\end{array}$ & $\begin{array}{c}0.11 \\
7,336\end{array}$ \\
\hline \multirow{2}{*}{ Model 2} & $\begin{array}{l}\text { Male } \\
\text { (all controls) }\end{array}$ & $\begin{array}{c}1.44^{* * *} \\
(0.02)\end{array}$ & $\begin{array}{c}1.43^{* * *} \\
(0.02)\end{array}$ & $\begin{array}{c}1.41^{* * *} \\
(0.01)\end{array}$ & $\begin{array}{c}1.40 * * * \\
(0.02)\end{array}$ \\
\hline & $\begin{array}{l}\text { R-squared } \\
\text { Observations }\end{array}$ & $\begin{array}{c}0.34 \\
4,780\end{array}$ & $\begin{array}{c}0.35 \\
4,691\end{array}$ & $\begin{array}{c}0.30 \\
7,427\end{array}$ & $\begin{array}{c}0.30 \\
7,336\end{array}$ \\
\hline
\end{tabular}

Exponentiated OLS coefficients reported. Interpreted as a percent change in Y given the change in X, e.g., the effect of 1.35 shows that men's actual wage is about 35 per cent larger than women's. Standard errors in parentheses, Sig. levels $* * * \mathrm{p}<0.01,{ }^{*} \mathrm{p}<0.05,{ }^{*} \mathrm{p}<0.1$

Source: Labour Force Survey 2009 and CV Keskus 2009, authors’ calculations

\footnotetext{
${ }^{9}$ Refer to Appendix Tabel A1 for models with all covariate effects reported.
} 
We observed no substantial differences between models estimated on the basis of raw and matched data. We take from this robustness exercise that the hypothesised selfselection affects our estimates only marginally and that the results based on the OLS model are sufficiently robust.

We believe that OLS provides reliable estimates about the gender-based differences in actual and expected earnings due to the fact that the pay gap is so sizable both at the aggregate as well as at the individual level. Self-selection mechanisms that normally affect pay differences are thus less pronounced because the wage is deeply embedded in the society. In other words, our findings hint at a substantial gender based wage discrimination. Empirically, we are able to further substantiate this conclusion by decomposing the wage difference into explained and unexplained part using a wellknown Oaxaca-Blinder decomposition method. If there is no gender-based discrimination, the entire wage difference (or its large part) should be explained due to the differences in the characteristics of men and women.

\section{Oaxaca-Blinder decomposition}

A common approach to investigate whether group differences in certain outcomes are indeed due to the baseline differences between these groups or due to some form of discrimination is to decompose these differences in a counterfactual manner suggested by Blinder (1973) and Oaxaca (1973). The idea is to ask how much of the overall wage difference is attributable to differences in the covariate values of $X$ (explained component) rather than the differences in the $\beta^{\prime} s$ (unexplained component). Table 4 demonstrates the decomposition analysis in two parts. Firstly, we report predicted wages for both men and women. The (geometric) means of actual wages are 9142.39 EEK for men and 6608.68 EEK for women, which amounts to a difference of 38 percent. In terms of expected wages the (geometric) means are 13113.40 for men and 9572.67 for women. The difference in expected wages is 37 percent in favour of men. In the second part of the wage gap decomposition the wage gap is divided into two parts.

The first part (explained) reflects the mean increase in women's wages if they had the same characteristics as men - this is the endowments part of the wage differential 
accounted for by the objective differences in educational levels, type of work, etc. In our case, adjusting women's endowments levels to the levels of men would not increase women's actual wages at all; in fact they would even fall by about 4 percentage points. The exact same is true for expected wages. It follows that differences in socio-demographic background variables and industry characteristics fail to account for the observed wage gap. The second term (unexplained) quantifies the change in women's wages when applying men's coefficients to the women's characteristics. A gap of 44 per cent in actual wages and a gap of 41 per cent in expected wages, which is roughly the same found in our fully controlled models (both, in the naive as well as matched models), remains entirely unexplained. Taken together, the decomposition exercise shows that the wage differential by gender is indeed induced by discrimination rather than objective differences in the levels of independent variables. Overall, these findings lend support to our earlier conclusion that pay difference between men and women are deeply embedded in Estonian society and are thus linked to structural discrimination.

Table 4. Blinder-Oaxaca decomposition of gender wage gap

$$
\text { ELS data on actual } \quad \text { CV data on expected }
$$

\begin{tabular}{lcc} 
Wage differential & wages & wages \\
\hline Predicted wage for men & $9142.39^{* * *}$ & $13113.40^{* * *}$ \\
& $(96.43)$ & $(108.67)$ \\
Predicted wage for women & $6608.68^{* * *}$ & $9572.67 * * *$ \\
& $(62.73)$ & $(63.14)$ \\
Difference & $1.38^{* * *}$ & $1.37 * * *$ \\
& $(0.02)$ & $(0.01)$ \\
Wage decomposition & & \\
\hline Explained & $-0.96^{* * *}$ & $0.96^{* * *}$ \\
& $(0.01)$ & $(0.01)$ \\
Unexplained & $1.44^{* * *}$ & $1.41^{* * *}$ \\
& $(0.20)$ & $(0.01)$ \\
\hline
\end{tabular}

Source: Labour Fource Survey 2009 and CV Keskus 2009, authors’ calculations 


\section{Discussion}

In this paper we investigated the gender wage differential in Estonia. We compared actual wages using Estonian Labour Force Survey (ELFS) data and expected (reservation) wages using the data from CV Keskus. CV Keskus' database includes online CVs of 200,000 job seekers in Estonia.

On average the expected wages were higher than actual wages. This is not surprising as expected wages most probably contain also some room for wage negotiations. As trade unions play a minor ${ }^{10}$ role in wage setting in Estonia, such a gap between expected and actual wages in most cases is a result of individual wage bargaining.

Surprisingly, gender wage gap in both cases was very similar. It appears as though women expect a 41 percent lower wage than men and this difference is also actualised in real earnings. The question is whether women expect lower wages and subsequently also get it, or whether women ask lower wages because they know that their wage base is $40 \%$ lower. In an imperfect information framework, asking for a high (males) or low (females) wage in job negotiations could be treated as a signal that implies high potential productivity. Therefore, if a person asks more, perhaps employers are in some cases also willing to pay more.

The second explanation for gender based unequal treatment is the employer's attitude. Employers in the high-skilled sector are reluctant to hire women because they expect women to leave the job for childbearing and caring work before employers can reap the benefits of their increased human capital (Acker, 2011). Feminist sociology relates wage inequalities to power differences between women and men, by which the bargaining processes within the family take place under specific economic, institutional, and ideological conditions (Iversen and Rosenbluth, 2010). One solution according to the authors is that men have to do half of the housework. Psychological studies relate gender based wage differences to men's higher self-confidence. A number of studies have shown that while both men and women exhibit overconfidence in certain situations, men are on average more likely to overstate their

\footnotetext{
${ }^{10}$ Union density in Estonia was 10\% (2009) and collective bargaining coverage about 32\% (European foundation homepage: http://www.eurofound.europa.eu/eiro/country/estonia_1.htm)
} 
characteristics relative to others (Barber and Odean, 2001). Men's relative overconfidence may thus contribute to the gender wage gap as a separate factor.

Irrespective of these potential explanations of gender wage gap, what strikes us the most is that the differences in actual and expected wages are remarkably similar to one another. Notice that this difference prevailed when using more rigorous matching or wage decomposition methods, providing further evidence of the substantial pay gap in Estonia.

Regarding specific conditional effects, we found that the pay gap is not uniformly distributed across all age groups. In particular, the gap did not occur until the age of 22. The young seem to be immune to gender based wage discrimination. Why is that? One potential explanation is that starting wages for first labour market entrants are relatively independent from their gender in Estonia. In other words, young men are treated as equal to young women. However, this changes dramatically when employees accumulate some work experience and grow older. More importantly, our findings suggest that wage differences are not due to the observed differences in characteristics of men and women, but due to the unexplained discriminatory factors.

Earlier studies have also found that if wage differences are substantial across education levels and women are on average more educated than men, then the gender wage gap is small (Blau and Kahn, 2000). Thus, it is particularly alarming that our evidence shows that females with a university degree earn even less than males with secondary education. This fact contradicts the general human capital theory where more years in education are usually awarded with higher labour earnings. In addition, we found that education is not diminishing the wage gap; on the contrary, the higher the level of education, the higher the wage gap. Clearly, these findings suggest the presence of the substantial 'glass-ceiling' effect for women in Estonia.

We would also like to highlight the relevance of policy in bridging the wage gap. It is widely accepted that men take more risks than women and that women make more of an effort to reconcile professional and family life, especially in such post-communist countries like Estonia, where the family model is still mostly patriarchal. An interesting debate emerged in the UK reflecting opposing views on low employment 
rates, cultural norms, and policy. Hakim (1995) criticised the feminist sociologists for creating new feminist myths about women's employment, and how they have allowed a desire to transform society to override their attention to evidence. However, Ginn et al. (1996) responded with the following:

"Although the reasons for women's low rate of full-time employment include cultural norms in the workplace and the family, as well as the demands of other caring and domestic work, the practical and financial difficulties posed by childcare remain a major obstacle in a country with among the poorest public childcare provision in the EU”.

Reflecting on the situation in the UK during Thatcher's social policy time, we believe that it also describes the situation in the Baltic countries and particularly in Estonia today as well. Low childcare assistance, shortage of pre-school childcare institutions etc., have created a situation where women have no choice than to accept relatively low wages compared with their male colleagues.

Only one policy, introduced ten years ago in Estonia, attempts to alleviate this problem for people on parental leave. From 2004 the parent's pay (parental benefit) allows one parent (in most cases women) to get a sufficient state-funded income during their first 1.5 years of parental leave. The amount of the parent's salary is the average of the six month's income prior to taking the leave, and it is limited by 1.5 times the national average wage. This was indeed the first step towards equalising the labour market opportunities in Estonia and increasing women bargaining power at home. Unfortunately, this tool only covers the first 1.5 years of child care; after that women will have to make difficult choices again between having more children or entering the labour market. As a consequence, after 10 years of existence, this policy fails to demonstrate the diminishing effect on the gender wage gap, which has persisted on the same level for the last 20-25 years.

If we look at broader institutional changes on gender issues, Estonia passed the Gender Equality Act in 2004, the Law of Equal Treatment was amended in 2008, and the institution of Gender Equality and Equal Treatment Commissioner were introduced in 2010. The latter should monitor compliance with the requirements of the Gender Equality Act and the Equal Treatment Act, accept applications from 
individuals, and provide opinions concerning possible cases of discrimination, while also analysing the effects of legal acts on the situation of women and men as well as on the minorities in the society. Therefore, and at least formally, these institutional changes are to some degree acknowledging the problems of gender equality and responding to them. However, when looking at the official reports of the office of the Commissioner, only 24 complaints were related to labour discrimination in 2013, out of the total of 70 .

We conclude by noting that compared to similar acts in older European countries, these institutional changes are still very recent, and that individual awareness and behaviour is lagging behind, changing cultural norms and institutional settings in Estonia. These doubts are well supported by the main findings in this paper demonstrating that the gender induced wage gap is still very large both in actual and expected earnings. 


\section{References}

Acker, J. (2011) "Women, Work, \& Politics: The Political Economy of Gender Inequality”, Contemporary Sociology: A Journal of Reviews, vol. 40, no. 5, pp 596597.

Aigner, D. and Glen, C. (1977) "Statistical Theories of Discrimination in Labor Markets”, Industrial and Labor Relations Review, vol. 30, no. 2, pp. 175-87.

Albrecht, J., Björklund A., Vroman, S. (2003) "Is There a Glass Ceiling in Sweden?" Journal of Labor Economics, vol. 21, no. 1, pp.145-177.

Anspal, S., Kraut, L., Rõõm, T. (2010) "Sooline palgalõhe Eestis” [Gender wage gap in Estonia]. Report, 131 p.

Arulampalam, W., Booth,A., Bryan, M. (2007) "Is There a Glass Ceiling over Europe? Exploring the Gender Pay Gap across the Wage Distribution”, Industrial and Labor Relations Review, vol. 60, no. 2, pp. 163-186.

Baffoe-Bonnie, J. and Ezeala-Harrison, F. (2005) "Incidence and Duration of Unemployment Spells: Implications for the Male-Female Wage Differentials”, The Quarterly Review of Economics and Finance, vol. 45, pp. 824-847.

Barber, B.M. and Odean, T. (2001) "Boys Will Be Boys: Gender, Overconfidence, and Common Stock Investment”, Quarterly Journal of Economics, 116, pp. 261-292.

Bartolucci, C. (2013) “Gender Wage Gaps Reconsidered A Structural Approach Using Matched Employer-Employee Data”, Journal of Human Resources, vol. 48, no. 4, pp. 998-1034.

Becker, G. S. (1957) The Economics of Discrimination. Chicago: University of Chicago Press.

Becker, G.S. (1964, $19752^{\text {nd }}$ ed.) Human Capital: A Theoretical and Empirical Analysis, with Special Reference to Education, 2nd ed. NBER http://papers.nber.org/books/beck75-1 11.02.2014

Becker, G S. (1985) "Human Capital, Effort, and the Sexual Division Labor”, Journal of Labor Economics, 3:1 Supp., pp. S33-S58.

Bergmann, B. (1974) "Occupational Segregation, Wages, and Profits When Employers Discriminate by Race or Sex", Eastern Economic Journal, 1:1-2, pp. 10310.

Blackaby D.H, Latreille, P.D., Murphy, O’Leary, N.C., Sloane, P.J. (2007) “An Analysis of Reservation Wages for the Economically Inactive”, Economics Letters, 97, pp. 1-5. 
Blau, F.D. (1998) "Trends in the Well-Being of American Women, 1970-1995", Journal of Economic Literature, 36, 1, pp. 112- 165.

Blau F. D., and Kahn L. M, (2000) "Gender Differences in Pay”, Journal of Economic Perspectives, vol. 14, no. 4, pp. 75-99.

Brown, S., Roberts, J., Taylor, K. (2011) “The gender reservation wage gap: Evidence from British Panel data”, Economics Letters, vol. 113, pp. 88-91.

Blinder, A. (1973) "Wage Discrimination: Reduced Form and Structural Estimates", Journal of Human Resource, vol. 8, no. 4, pp. 436-455.

Boyd, C. L., Epstein, L., Martin, A. D. (2010). "Untangling the causal effects of sex on judging”, American journal of political science, 54(2), pp. 389-411.

Böheim, R., Himpele, K., Mahringer, H., Zulehner, C. (2013) “The gender wage gap in Austria: eppur si muove!“ Empirica, 40, pp. 585-606.

Cameron, A. C., and Trivedi, P. K. (2009) Microeconometrics Using Stata. Stata Press books.

Charles, A. (2011) "Fairness and Wages in Mexico's Maquiladora Industry: An Empirical Analysis of Labor Demand and the Gender Wage Gap”, Review of Social Economy, vol. 69, no. 1, pp. 1-28.

Datta Gupta, Oaxaca, R. L. Smith, N. (2006) "Swimming Upstream, Floating Downstream: Comparing Women's Relative Wage Progress in the United States and Denmark”, Industrial and Labor Relations Review, vol. 59, no. 2, pp. 243-266.

Diamond, A., and Sekhon, J.S. (2005) "Genetic matching for estimating causal effects: A general multivariate matching method for achieving balance in observational studies”, Review of Economics and Statistics, (0).

Eamets, R. and Masso, J. (2005) "Labour Market Flexibility and Employment Protection Regulation in the Baltic States", European Journal of Industrial Relation, vol. 11, no 1, pp. 71-90.

England, P. and Browne, I. (1992) "Trends in Women's Economic Status", Sociological Perspectives, vol. 35, No. 1, Women in the Workplace: Toward True Integration, pp. 17-51.

England, P. (1982) "The Failure of Human Capital Theory to Explain Occupational Sex Segregation”, The Journal of Human Resources, vol. 17, no. 3, pp. 358-370.

Eurostat (2014) Gender pay gap in unadjusted form http://epp.eurostat.ec.europa.eu/tgm/table.do?tab=table\&init=1\&language=en\&pcode =tsdsc340\&plugin=1 Assessed 10 February 2014.

Ginn, J., Arber, S., Brannen, J., Dale, A., Dex, S., Elias, P., Moss, P., Pahl, J., 
Roberts, C., Rubery, J. (1996) "Feminist Fallacies: A Reply to Hakim on Women's Employment”, The British Journal of Sociology, vol. 47, no. 1, pp. 167-174.

Hakim, C. (1995) “Five Feminist Myths About Women's Employment”, British Journal of Sociology, vol. 46, no. 3, pp. 429-455.

Hellerstein, J. and Neumark D. (1999) "Sex, Wages, and Productivity: An Empirical Analysis of Israeli Firm-Level Data”, International Economic Review, vol. 40, no 1, pp. 95-123.

Hellerstein, J., Neumark, D., Troske, K. (1999) "Wages, Productivity, and Worker Characteristics: Evidence from Plant-Level Production Functions and Wage Equations”, Journal of Labor Economics, vol.17, no. 3, pp. 409-446.

Hinnosaar, M. and. Rõõm, T. (2003) “The Impact of Minimum Wage on the Labour Market in Estonia: An Empirical Analysis”, Bank of Estonia, Working Papers, No. 8.

Ho, D. E., Imai, K., King, G., Stuart, E. A. (2007) "Matching as nonparametric preprocessing for reducing model dependence in parametric causal inference" Political analysis, vol.15 no. 3, pp. 199-236.

Iversen, T. and Rosenbluth, F. (2010) "Women, Work, \& Politics: The Political Economy of Gender Inequality” by New Haven, CT: Yale University Press, 2010, $202 \mathrm{pp}$

Jarell S. B. and Stanley T.D. (2004) "Declining Bias and Gender Wage Discrimination? A Meta-Regression Analysis”, The Journal of Human Resources, vol. 39, no. 3, pp. 828-838.

Leping, K.-O. and Toomet, O. (2008) "Emerging ethnic wage gap: Estonia during political and economic transition”, Journal of Comparative Economics, vol. 36, pp. 599-619.

Mincer, J. (1958) “Investment in Human Capital and Personal Income Distribution”, Journal of Political Economy, vol. 66, no. 4, pp. 281-302.

Mincer, J. (1974) “Schooling, Experience and Earnings”, New York: National Bureau of Economic Research.

Mincer, J. and Polachek, S. (1974) "Family investments in human capital: earnings of women”, Journal of Political Economy, 82(2), S76-S108

Mõtsmees, P. and Meriküll, J. (2012) "What you ask, is what you get: gender reservation wage gap”, University of Tartu, mimeo.

Newell, A. and Reilly, B. (2001) "The Gender Pay Gap In The Transition From Communism: Some Empirical Evidence”, Economic Systems, 25, pp. 287-304.

Nyhus, E.K. and Pons, E. (2012) "Personality And The Gender Wage Gap”, Applied Economics, 44, pp. 105-118. 
Oaxaca, R. (1973) "Male-Female Wage Differentials in Urban Labor Markets", International Economic Review, vol. 14, no. 3, pp. 693-709.

Philips, K. (2001) "The Changes in Valuation of Human Capital During the Transition Process in Estonia”, Dissertationes Rerum Oeconomicarum Universitas Tartuensis, No. 6, Tartu 2001

Polachek, S.W. (2003) "Mincer's Overtaking Point and the Life Cycle Earning Distribution”, Review of Economics of the Household, 1, pp. 273-304.

Rubin, D. B. (2006) "Matched sampling for causal effects", Cambridge University Press.

Rõõm, T. and Kallaste E. (2004) "Men and Women in the Estonian Labour Market: An Assessment of the Gender Wage Gap", Praxis Policy Analysis no 8 http://praxis.ee/fileadmin/tarmo/Publikatsioonid/PA82004_eng.pdf

Semykina, A. and Linz, S.J. (2010) "Analyzing the Gender Pay Gap in Transition Economies: How Much Does Personality Matter?” Human Relations, vol. 63, no. 4, pp. 447-469.

Stanley, T.D. and Jarrell, S. (1998) "Gender Wage Discrimination Bias? A MetaRegression Analysis”, Journal of Human Resources, vol. 33, no.4, pp. 947-973.

Satatistics Estonia (2014) The Estonian Labour Force Survey, available at: http://pub.stat.ee/pxweb.2001/I_Databas/Social_life/09Labour_market/04Employed_persons/02Annual_s tatistics/ML_047.htm (accessed 21 Janury 2014).

Vöörmann, R. (2000) “Men and Women on the Labour Market Wage Rations”, in. Maimik, P., Mänd, K., Papp, Ü. (Toim.). Towards a balanced society: women and men in Estonia (46 - 53). Tallinn: ÜRO Arenguprogramm Eestis.

Weichselbaumer, D. and Winter-Ebmer, R. (2005) “A Meta-Analysis Of The International Gender Wage Gap”, Journal of Economic Surveys, vol. 19, no. 3, pp. 479-511. 


\section{Appendix A}

Table A1. The effect of gender on wages (all models)

\begin{tabular}{|c|c|c|c|c|}
\hline \multirow{2}{*}{$\begin{array}{l}\text { Data: } \\
\text { Dependent variable: } \\
\text { Raw or matched data: }\end{array}$} & \multicolumn{2}{|c|}{$\begin{array}{l}\text { ELS data on actual wages } \\
\mathrm{y}=\text { reported actual wage }\end{array}$} & \multicolumn{2}{|c|}{$\begin{array}{c}\mathrm{CV} \text { data on expected wage } \\
\mathrm{y}=\text { reservation wage }\end{array}$} \\
\hline & $\begin{array}{c}\text { Raw } \\
\text { Model } 1\end{array}$ & $\begin{array}{l}\text { Matched } \\
\text { Model } 2\end{array}$ & $\begin{array}{c}\text { Raw } \\
\text { Model } 3\end{array}$ & $\begin{array}{l}\text { Matched } \\
\text { Model } 4\end{array}$ \\
\hline $\begin{array}{l}\text { Male } \\
\text { (Base: female) }\end{array}$ & $\begin{array}{l}1.44 * * * \\
(0.02)\end{array}$ & $\begin{array}{l}1.43^{* * *} \\
(0.02)\end{array}$ & $\begin{array}{l}1.41^{* * *} \\
(0.01)\end{array}$ & $\begin{array}{l}1.40^{* * *} \\
(0.02)\end{array}$ \\
\hline Age & $\begin{array}{l}0.99 * * * \\
(0.00)\end{array}$ & $\begin{array}{l}0.99 * * * \\
(0.00)\end{array}$ & $\begin{array}{l}1.01^{* * *} \\
(0.00)\end{array}$ & $\begin{array}{l}1.01^{* * *} \\
(0.00)\end{array}$ \\
\hline Children & $\begin{array}{l}1.00 \\
(0.01)\end{array}$ & $\begin{array}{c}1.01 \\
(0.01)\end{array}$ & $\begin{array}{l}1.02^{* *} \\
(0.01)\end{array}$ & $\begin{array}{c}1.00 \\
(0.01)\end{array}$ \\
\hline $\begin{array}{l}\text { Higher education } \\
\text { (Base: primary) }\end{array}$ & $\begin{array}{l}1.50 * * * \\
(0.04)\end{array}$ & $\begin{array}{l}1.52^{* * *} \\
(0.04)\end{array}$ & $\begin{array}{l}1.45^{* * *} \\
(0.03)\end{array}$ & $\begin{array}{l}1.45^{* * *} \\
(0.04)\end{array}$ \\
\hline $\begin{array}{l}\text { Secondary education } \\
\text { (Base: primary) }\end{array}$ & $\begin{array}{l}1.13^{* * *} \\
(0.02)\end{array}$ & $\begin{array}{l}1.15^{* * *} \\
(0.02)\end{array}$ & $\begin{array}{l}1.11 * * * \\
(0.02)\end{array}$ & $\begin{array}{l}1.11 * * * \\
(0.02)\end{array}$ \\
\hline $\begin{array}{l}\text { Married } \\
\text { (Base: not married) }\end{array}$ & $\begin{array}{l}1.08^{* * *} \\
(0.02)\end{array}$ & $\begin{array}{l}1.08^{* * *} \\
(0.02)\end{array}$ & $\begin{array}{l}1.06^{* * *} \\
(0.01)\end{array}$ & $\begin{array}{l}1.06^{* * *} \\
(0.01)\end{array}$ \\
\hline $\begin{array}{l}\text { White collar worker } \\
\text { (Base: blue collar) }\end{array}$ & $\begin{array}{l}1.30^{* * * *} \\
(0.02)\end{array}$ & $\begin{array}{l}1.27^{* * * *} \\
(0.02)\end{array}$ & $\begin{array}{l}1.17^{* * *} \\
(0.01)\end{array}$ & $\begin{array}{l}1.19^{* * *} \\
(0.01)\end{array}$ \\
\hline $\begin{array}{l}\text { Estonian ethnicity } \\
\text { (Base: russian ethn.) }\end{array}$ & $\begin{array}{l}1.17^{* * * *} \\
(0.02)\end{array}$ & $\begin{array}{l}1.17^{* * * *} \\
(0.02)\end{array}$ & $\begin{array}{l}1.11^{* * * *} \\
(0.02)\end{array}$ & $\begin{array}{l}1.10^{* * * *} \\
(0.03)\end{array}$ \\
\hline $\begin{array}{l}\text { Mining } \\
\text { (Base: manufacturing) }\end{array}$ & $\begin{array}{l}1.28^{* * *} \\
(0.08)\end{array}$ & $\begin{array}{l}1.27^{* * *} \\
(0.06)\end{array}$ & $\begin{array}{l}1.23^{* *} \\
(0.11)\end{array}$ & $\begin{array}{l}1.33^{* *} \\
(0.16)\end{array}$ \\
\hline Construction & $\begin{array}{l}1.12^{* * *} \\
(0.02)\end{array}$ & $\begin{array}{l}1.13^{* * *} \\
(0.03)\end{array}$ & $\begin{array}{c}1.09 \\
(0.06)\end{array}$ & $\begin{array}{c}1.06 \\
(0.06)\end{array}$ \\
\hline Commerce & $\begin{array}{l}0.94^{* * *} \\
(0.02)\end{array}$ & $\begin{array}{l}0.95^{* * *} \\
(0.02)\end{array}$ & $\begin{array}{l}1.06^{* * *} \\
(0.02)\end{array}$ & $\begin{array}{l}1.06^{* *} \\
(0.02)\end{array}$ \\
\hline $\begin{array}{l}\text { Hotels, restaurants, } \\
\text { cafeterias }\end{array}$ & $\begin{array}{l}0.93^{* *} \\
(0.03)\end{array}$ & $\begin{array}{l}0.92 * * \\
(0.03)\end{array}$ & $\begin{array}{l}1.00 \\
(0.01)\end{array}$ & $\begin{array}{l}1.00 \\
(0.01)\end{array}$ \\
\hline $\begin{array}{l}\text { Transport, } \\
\text { communications }\end{array}$ & $\begin{array}{l}1.10^{* * *} \\
(0.02)\end{array}$ & $\begin{array}{l}1.10^{* * *} \\
(0.03)\end{array}$ & $\begin{array}{l}0.95^{* *} \\
(0.02)\end{array}$ & $\begin{array}{c}0.96 * \\
(0.02)\end{array}$ \\
\hline Finance & $\begin{array}{l}1.30^{* * * *} \\
(0.06)\end{array}$ & $\begin{array}{l}1.35^{* * *} \\
(0.07)\end{array}$ & $\begin{array}{c}1.03^{*} \\
(0.02)\end{array}$ & $\begin{array}{c}1.03 \\
(0.03)\end{array}$ \\
\hline Real estate & $\begin{array}{l}0.90^{* * *} \\
(0.02)\end{array}$ & $\begin{array}{l}0.90^{* * *} \\
(0.03)\end{array}$ & $\begin{array}{l}1.09^{* * *} \\
(0.03)\end{array}$ & $\begin{array}{l}1.11^{* * *} \\
(0.03)\end{array}$ \\
\hline $\begin{array}{l}\text { Public administration, } \\
\text { health care }\end{array}$ & $\begin{array}{l}1.05^{* *} \\
(0.02)\end{array}$ & $\begin{array}{l}1.05^{* *} \\
(0.02)\end{array}$ & $\begin{array}{l}1.03^{* *} \\
(0.02)\end{array}$ & $\begin{array}{l}1.04 * \\
(0.02)\end{array}$ \\
\hline Other public services & $\begin{array}{l}0.85^{* * *} \\
(0.03)\end{array}$ & $\begin{array}{l}0.89 * * * \\
(0.03)\end{array}$ & $\begin{array}{c}0.95 \\
(0.05)\end{array}$ & $\begin{array}{c}0.91^{*} \\
(0.05)\end{array}$ \\
\hline Constant & $\begin{array}{l}5,150.00^{* * *} \\
(169.33) \\
\end{array}$ & $\begin{array}{l}5,089.27 * * * \\
(195.80)\end{array}$ & $\begin{array}{l}5,025.85 * * * \\
(159.50)\end{array}$ & $\begin{array}{l}5,295.97 * * * \\
(202.15) \\
\end{array}$ \\
\hline Observations & 4,780 & 4,691 & 7,427 & 7,336 \\
\hline R-squared & 0.34 & 0.35 & 0.30 & 0.30 \\
\hline Wald test & $692.86 * * *$ & $539.15^{* * *}$ & $1248.13 * * *$ & $927.26 * * *$ \\
\hline
\end{tabular}

OLS coefficients; Standard errors in parentheses, Sig. levels ${ }^{* * *} \mathrm{p}<0.01,{ }^{* *} \mathrm{p}<0.05,{ }^{*} \mathrm{p}<0.1$

Wald test sets male dummy to 0

Source: Labour Fource Survey 2009 and CV Keskus 2009, authors' calculations 